\title{
Legal Protection Principle for Workers Terminated Due to Industrial Digitalization
}

\author{
Sidi Alkahfi Setiawan ${ }^{1} \quad$ Dominikus Rato $^{2} \quad$ Aries Harianto $^{3} \quad$ Dyah Ochtorina Susanti ${ }^{4}$ \\ 1.Sidi Alkahfi Setiawan, Law Doctoral Program Student of Jember University \\ 2.Dominikus Rato, Prof. Doctor of Law Faculty of Jember University, in the field of Customary Law \\ 3.Aries Harianto, Doctor of Law Faculty of Jember University, in the field of Labor Law \\ 4.Dyah Octorina Susanti, Doctor of Law Faculty of Jember University, in the field of Civil Law
}

\begin{abstract}
Employment termination caused by industrial digitalization is contrary to the constitutional rights of workers. The essence of this right indicates that everyone has the right to get a decent living and fair treatment through a constructive and proportionate working relationship. Constitutional rights are an inseparable part of human rights. It is a primary right, thus the state is obliged to protect and realize it through the state constitution and existing positive law. One of the fundamental constitutional rights is the protection of workers due to terminations. However, a legal vacuum exists regarding the protection for labour due to industrial digitalization. The phenomenon of industrial digitalization is unavoidable, workers will be greatly harmed when most companies digitize simultaneously for the sake of efficiency. Such protection must be regulated proportionally which is oriented towards fulfilling the interests of workers as an impact of the company's efficiency due to digitalization. The legal principles of providing legal protection for workers who have been terminated due to digitalization include, first, the principle of legal protection guarantee for workers and their families; Second, the principle of fair compensation; Third, the principle of mutual will of parties involved in the working relationship; and Fourth, the principle of authoritative intervention.
\end{abstract}

Keywords: Constitutional Rights, Industrial Digitalization, and Termination of Employment.

DOI: $10.7176 / \mathrm{JLPG} / 117-02$

Publication date: January $31^{\text {st }} 2022$

\section{Introduction}

The 4.0 industrial revolution does not require human energy and thoughts at work. This revolution replace human by machine which is able to communicate and connect with one another. Artificial intelligence is starting to replace human thinking abilities, especially in terms of decision making. For example, in the banking world, banks are starting to use machines to analyse loan applications as well as to make decisions based on data and track records. The rapid development of technology affects employment sector. There are at least 50 thousand workers in the banking sector have been terminated due to digitalization. Gradual termination of employment of banking sector began since 2016. The terminations were carried out for efficiency. Certain position such as teller, customer service, and banking sales began to be slowly reduced.

The above statistical fact indicates that employment termination as a form of efficiency in Indonesia is undeniable threat. The Act Number 13 of 2003 on Manpower (hereinafter referred to as UUK) has regulated various dynamics of workers termination, such as resignation, without notification, company's bankrupt, contract termination of Particular Time Agreement, and efficiency. However, termination of employment to reduce number of workers is referred to as company efficiency.

Article 164 paragraph (3) of the UUK states:

The entrepreneur may terminate the employment because the enterprise has to be closed down not due to continual losses for two years nor force majeure, but rather due to efficiency, the company shall entitle certain amount of severance pay and reward for workers stipulated in two different regulations. Severance pay referred to Article 156 Paragraph (2) of the UUK is the amount of two years of work, and the reward pay for one term of service referring to Article 156 Paragraph (3) of the UUK, and compensation pay for one term is according to Article 156 Paragraph (4) of the UUK.

In short, termination of employment carried out under efficiency is legal. However, Article 164 Paragraph (3) of the UUK allowing termination for the sake of efficiency has been countered by Decision of the Constitutional Court of the Republic of Indonesia precisely Decision Number 19/PUU-IX/2011. This verdict stated that the enterprise shall be permanently closed down to carry out massive termination of employment. The annulled norm has been declared contrary to the 1945 Constitution of the Republic of Indonesia. The companies closed down temporary and terminated its workers. Article 164 Paragraph (3) contradicts the main moral value of Manpower Law. The Article 151 Paragraph (1) states that the entrepreneur, worker/labourer, and or the tradel labour union, and the government must make all efforts to prevent termination of employment from taking place".

The government has to ensure that its entire citizen shall have access to work which is commonly referred 
to as right to work. Employment is a means of every individual to achieve independence and prosperity. All government policies shall be oriented on reducing number of unemployment and improving the quality of work environment (Agusmidah, 2011:214-215). The state shall protect all workers/ labourers through various policies, one of which through the issuance of law and regulations which is oriented toward improving employees welfare. It cannot be contested as it has been recognized as part of human rights stipulated by the Constitution.

Based on the above short elucidation, the termination of employment caused by industrial digitalization raises various problems as follows:

1. Philosophical problem. On the philosophical problem, the occurrence of constitutional injustice due to the absence of legal protection for terminated workers/labourers due to industrial digitization will distort the values of Pancasila Industrial Relations. In addition, termination of employment which is undeniable due to industrial digitalization is an indication of disharmony against Article 27 paragraph (2) and Article 28D paragraph (2) of the 1945 Constitution of the Republic of Indonesia

2. Juridical problem, the occurrence of worker efficiency due to industrial digitization is contrary to Article 151 paragraph (1) of the UUK. This article states "The entrepreneur, worker/labourer, and or the trade/ labour union, and the government must make all efforts to prevent termination of employment from taking place. The Constitutional Court through Decision Number 19/PUU-IX/2011 created poor protection for entrepreneurs because the arrangements in the decision did not accommodate the reality of industrial digitization which caused termination of employment.

3. Theoretical problem, there has been a vacuum in the role of the welfare law state in employment relations, where industrial digitalization as a manifestation of economic law does not run linearly with the welfare of workers. The digitalization of industry clearly threatens the principle of legal purpose in providing worker protection, due to the absence of the state.

4. Sociological problems, which arise as a result of the digitalization of the company's industry resulting in Termination of Employment and social impacts in the form of increasing unemployment statistics and their negative consequences, such as high crime rates arising from social disparities that arise.

Based on the above information, a new labour law system exists. It is done through the issuance of UUK and Act Number 11 of 2020 concerning Job Creation (UUCK) which mutatis mutandis also brings new legal issues. Thus, there are several legal issues will be further analysed, namely what are the legal protections for workers terminated due to industrial digitalization? What are the legal principles used in providing legal protection for workers/labourers terminated due to industrial digitalization?

\section{Research Method}

This study belongs to normative legal research which is oriented to legal norm analysis resulted in argumentation, theory and concept as a prescription to answer legal issues by implementing law and regulations, verdicts, and other legal materials. This study obtains wrong, appropriate or right answers. It applies statutory approach, conceptual approach, and case approach (Peter Mahmud Marzuki, 2019:29-36). Statutory and conceptual approached are used examine issues of legal protection for workers terminated due to industrial digitalization based on positive law and several similar issues to obtain comprehensive understanding in constructing complete idea. Furthermore, conceptual approach is applied to arrange legal principles used as reference of legal renewal for workers protection due to digitalization.

\section{Results and Discussion}

\subsection{Legal Protection for Terminated Indonesian Workers due to Industrial Digitalization}

The legal protection aims at protecting the values of Human Rights to be injured. One of government duties is to ensure every citizen get his rights, such as giving sense of both mental and physical security, and preventing several threats both from internal and external parties (Satjipto Rahardjo, 2000: 74). Protection of dignity is also the scope of legal protection which is part of human rights (Philipus M. Hadjon, 1987: 25). As legal subject, human will always be bound by their rights and obligations toward their fellow human especially in taking legal actions (CST Kansil, 1989: 102). According to Setiono, legal protection is an effort to protect all citizens from government arbitrary actions and is aimed to create order, security, and to maximize human to maintain their dignity (Setiono, 2004:3).

Indonesia adheres to the welfare state model with an industrial relations system of economic democracy as its basis as being stipulated by Article 27 Paragraph (2) jo. Article 28D Paragraph (2) of the 1945 Constitution of the Republic of Indonesia which clearly stated that everyone has the right to receive wages and fair and equal treatment for humanity. Therefore, the state is not only obliged to provide job vacancies, but also to ensure all workers/ labourers receive decent living and fair treatment. This concept is supported by Kartasapoetra stating that employment is not merely economic oriented but it carries the value of humanity (Asri Wijayanti, 2010:112). The ideal of Indonesian labour law is stipulated in the Article 27 Paragraph (2) jo. Article 28D Paragraph (2) of the 1945 Constitution of the Republic of Indonesia. It is inline with the principle of economic 
democracy of Pancasila which is supporting the national development goal to achieve communities' welfare.

Labour is one of development goal main actors since it has strategic role to achieve the objective. The development of manpower system is aimed at protecting labourers/workers interests. It requires all efforts to improve labours quality and contribution for national development. Therefore, Pancasila Industrial Relations shall be the proper system to be applied because philosophically, the essence and purpose of this system is inline with the Indonesian legal ideals namely to grant all Indonesian citizens' welfare through the creation of a just and prosperous society.

The Pancasila Industrial Relation system is characterized by the opinion that in a work relationship, human is dignified and equal and has the ability to communicate, coordinate, and consult so that preventive efforts on errors can be minimized; and the existence of deliberation and consensus in solving problems, and the absence of company closures (Muhammad Sadi and Sobandi, 2020: 21).

The Indonesian Industrial Relations is an integral part of Pancasila Industrial Relations system, while the system of industrial relationship is a sub-system of the Indonesian labour integral system as a part of Pancasila Economic Democracy System, due to the fact that the state has the efforts to build proportional position between entrepreneurs and workers/labourers, and to prioritize deliberation process for solving problems.

All citizens' rights are the carried out by the State to ensure its people welfare. Though, there are differences found in the implementation. The readiness of the state and its tools must be strengthened, especially financing aspect to support the welfare of all its citizens. The state shall make every effort to ensure that the standard of living of its citizens is guaranteed because society cannot be separated from government policies and actions to defend their rights and dignity. In Indonesia, all aspects are regulated in detail in the form of regulations because with these regulations the features of the rule of law will appear clearly, conceptually and theoretically.

The number of workers who do not meet the qualifications especially in the manufacturing sector shows their unpreparedness to adapt the 4.0 industrial revolutions which is identical with digital economy and automation. Therefore, the government has made various preparations to face the industrial revolution 4.0, one of which is the empowerment of human resources. The government through the Ministry of Finance has allocated more funds in the education and health sectors. The Ministry of Industry has also provided several strategies to deal with the industrial revolution 4.0, including starting to create a stimulus to encourage the use of digital technology in the industrial sector and increasing internet technology literacy.

Employment termination due to industrial digitalization is caused by massive efficiency of manufactures to reduce production costs and to increase benefits. Profit orientation inevitably makes entrepreneurs choose software technology and artificial intelligence. Even Jeremy Rifkin in The End of Work predicts that there will be massive termination of workers where most companies no longer need workers. By the existence of technology disruption, the community shall be more vigilant because the position of the state, entrepreneurs and workers has changed. The state cannot unilaterally determine the survival or failure of a business when the entrepreneur does not comply with state regulations (Jeremy Rifkin, 1996: 19-21).

Massive and complex technology disruption requires all parties' formulation, namely the state, entrepreneurs, and workers/labourers to create a balance. The termination of employment issue will not meet a common ground if the parties are still adamant about their respective interests. In this case, the termination mechanism should be clear and flexible in its implementation to avoid miss-interpretation, be it the entrepreneur or the worker/labourer themselves.

\section{a. Economic Aspect Protection}

In this modern time, social status is required besides fulfilling life necessities. To improve social status, one needs an occupation that will greatly impact the lifestyle. Work is a necessity for every human being to achieve maximum prosperity, because a person will earn income and career path. These two things are absolute to achieve a better life.

In its development, to improve the performance and quality of the workforce, it is necessary to guarantee a safe and decent life for someone that can also lead to an increase of workers/labourers quality of life by strengthening protection for workers/labourers who prioritize their own dignity and human rights (Abdul Khakim, 2003: 12). The rapid development of era and technology demands protection of workers, because labour protection is an important thing to be supported due to the increasing risks and responsibilities of workers. Indirectly, the implementation of the guarantee is an appreciation to see the value created by the workers/labourers who have contributed to the company through their ideas and thoughts. Likewise, job security which is based on Pancasila and the 1945 Constitution of the Republic of Indonesia can be considered as an important labour promotion for national integration and development. Thus, it is important for public authorities to increase protection for workers (I. Made Udiana, 2018: 26).

In Indonesia, employment is regulated by the Manpower Law and Job Creation Law. The disharmony of entrepreneurs and workers/labourers mostly causes the occurrence of employment issues (Ashabul Kahfi, 2016: 62). Since work relation problems is identical with elements of social, economic, and political welfare, 
termination of employment shall be seriously considered to achieve fair national development goals (Aries Harianto, 2016:71-73).

Termination of employment causes social imbalances as a result of the company's inability to meet the termination standards imposed on its workers. Companies will generally carry out unilateral termination which is not in accordance with the applicable regulations. In principle, the company is obliged to protect and prosper each of its workers in order to create a harmonious relationship between workers/labourers and employers without any structural coercion from stronger parties (employers) to more vulnerable individuals (labourers/workers). Along with the improvement of information technology, besides having a positive impact, especially as far as modernization and advancement of information is concerned, it also has a negative impact on the employment sector.

The negative impact of information technology advancement is reflected in the use of technology that develops mechanically in the company which no longer need human for the program. This change is referred to as digitalization. Efficiency is a justification of enterprise to terminate its workers. In this case, digitalization is usually taken for the sake of efficiency.

The affectivity mentioned indicates that company will impose restrictions on the use of resources into the interactions used in the company's workflow. It is seen through labours limitation by replacing them with machines or the transformation from all manual structures to advanced ones. For workers, termination is the beginning of livelihood loss affecting domino impacts for their families and government. Due to the fact that, in this digitalization era, finding job is hard (Aries Harianto, 2021:31).

Multi-interpretation of worker termination both by the statutory regulations and experts' doctrines will at least provide more detail definitions of termination of employment. In principle, the guidelines are contained in Article XII Article 150 to Article 172 of the UUK. Then Article 1 number 25 of the UUK has given approval on termination, especially the most common way to terminate a work relationship due to certain things which end working relationship between the two parties, i.e., the worker/labourer and the entrepreneur. Halim opines that termination of employment is caused by certain factor. It is taken by entrepreneurs to their workers as an end of their work relationship. Work relation occurs due to certain consensus between entrepreneurs and workers (Cristoforus Valentino AP, 2017: 68).

A work agreement is an arrangement containing rights ad obligations plan of parties involved. It also regulates the framework to be carried out by the workers/labourers depending on the provisions that will be given and will be recognized by the workers/labourers. Termination of employment is closely related to workers rights. Both are viewed as two inseparable things since they lead to an attachment and commitment between workers and the company. The expiry of employment relationship will clearly disrupt the chain of rights and commitment contained therein.

Rewards fees for years of service are regulated by the Article 156 Paragraph (3) of the UUK, like severance pay, both are calculated based on the total years of service. Points a to $h$ mentioned that workers/labourers receiving reward pays shall be at least in 3 years of service or more, or even up to 24 years or more.

Wiwoho Siedjono opined that reward fee is not only given to workers/labourers that are good for the company. However, every terminated worker/labourer that has been worked for 5 years or more she is entitled to an award pay (Agung Prasetyo Wibowo, 2021: 76).

Then the compensation money is regulated in Article 156 Paragraph (4) of the UUK, in its provisions a worker/ labourer has the right to get compensation for rights, including:

1. Available annual leave;

2. Transportation cost of workers/ labourer to work;

3. Reimbursement of housing costs and health insurance; and

4. Provision of compensation based on the work agreement.

According to the UUK, the right protection for workers/ labourers is interpreted that payment received by workers is a form of wages protection to make a living for their families. Furthermore, Article 154 paragraph (1) of the UUK regulated that every entrepreneur is obliged to grant severance pay and/or reward pay and compensation for entitlements submitted to workers/ labourers concerned.

\section{b. Social Aspect Protection}

Social security as a form of employment protection shall be granted by the state to workers/labourers. It is an effort to increase dignity and welfare of workers/labourers in order to maximize the success of national development (Dodi Satriawan, Agus Joko Pitoyo, and Sri Rum Giyarsih, 2020: 558).

Work relationship shall be directed to constructive relations based on Pancasila and the 1945 Constitution of the Republic of Indonesia. Both parties shall have mutual understanding and respect the rights, obligations and roles of each other. The provision of social security to workers is not necessarily intended for the workers themselves but their families, if they pass away, sick and other unfortunate conditions (Ida Ayu Sadnyini dan Milton Gabe L. Tobing, 2020: 109). Some of the social security benefits that workers/labourers receive include: 1. Health Care Insurance (hereinafter referred to as JPK) 
This service is provided through cooperating partners that have met the qualifications according to the Organizing Body. It is provided in a structured, systematic and sustainable manner. This health insurance is carried out comprehensively, starting from the prevention and cure of disease, to the recovery and improvement of health.

2. $\quad$ Pension Plan (hereinafter referred to as JHT)

This plan is prepared when workers/labourers are no longer in a productive condition such as retirement, passing away and disability.

3. Death Insurance (hereinafter referred to as JK)

This program is addressed to the heirs of the worker/labourer if the death is not caused by a work accident. It is provided to lighten the family's burden such as funeral costs and other additional costs.

\section{c. Job Access Insurance Protection}

Legal arrangement of digitalization is referred to Article 164 Paragraph (3) of the UUK. This article stated that entrepreneur cannot terminate workers for the sake of efficiency if the enterprise does not suffer continual losses for 2 years or force majeure. In addition, employers are obliged to grant severance pay (two terms of service), reward pay (one term of service), and certain amount of compassion pay as stipulated by the Article 156 Paragraph (4) of the UUK (Siti Ummu Adillah and Sri Anik, 2015: 560).

Efficiency is one of the main reasons for termination of employment. This efficiency is carried out through reducing number of labour with the aim of increasing profits, one of which is through digitalization. Digitalization is often taken by companies to survive and thrive in an increasingly complex era of disruption (Sudiarawan, 2018: 797).

Companies are required to be able to carry out business processes appropriately in order to maximize profits and minimize existing losses. However, termination of employment shall be carried out in accordance with the provisions of the UUK and UUCK. The state must be present as a third party to be able to equalize the imbalance position of employers and workers. The prohibition of unilateral termination and the efforts to consider all the consequences arising from layoffs are form of representation of the state as a balancing party that must provide various affirmative policies to workers/ labourers (Edi Suharto, 2011: 41).

Affirmative policies can be carried out through job loss insurance. It is implemented through the Job Loss Insurance (hereinafter referred to as JKP) program. JKP also provides several benefits to workers/labourers, including information on job vacancies, competency training, and cash payments. To get this benefit, workers/labourers must first be registered as participants (Hartini Retnaningsih, 2019: 167). The status of an Indonesian citizen and a maximum age of 54 years and having a working relationship are the main requirements to register for the JKP program. The phrase having a working relationship refers to work agreements such as a Specific Time Work Agreement (PKWT) or an Indefinite Work Agreement (PKWTT) to register as a JKP participant.

JKP membership has been integrated with BPJS Employment. The funding of this program refers to Article 11 PP No. 37 of 2021. The participants pay a contribution of $0.46 \%$ per month from one month's wages for workers/labourers with an upper limit of 5 million rupiah in accordance with the provisions of PP. 37 of 2021. Furthermore, the Central Government also pays $0.22 \%$, while other contributions sourced from the JKK program contributions at $0.14 \%)$ and $\mathrm{JK}(0.01 \%)$.

JKP has several benefits for workers/labourers, including access to job vacancies information, cash and competency training that workers only get if they have a minimum contribution period of 12 months in 24 months and have paid a minimum of continual 6 months of contributions before termination takes place. If a participant experiences permanent/total disability, resigns, retires and passes away, the participant cannot receive JKP benefits. As for PKWT workers, JKP can only be submitted if termination happened before the end of the contract. Companies have an obligation to register their workers/labourers to the JKP program. The imperative provisions are contained in Article 37 PP No. 37 of 2021. The company is obliged to guarantee workers/labourers to get JKP benefits. However, micro entrepreneurs are not included in this provision.

\subsection{The Formulation of Labour Protection Principle of Workers Terminated due to Digitalization}

In the industrial era 4.0, Indonesia's labour conditions will experience changes or transformations, whether in the structural form and subject of individual workers. Low education will have an impact on low use of technology, and uneven development will end in structural changes (Jan Luiten van Zanden and Daan Marks, 2012: 13). In addition, Indonesia has an abstract employment relationship in the Indonesian Manpower Law which requires the formulation and changes to the concept of employment relations in industrial relations in the UUK. The UUK stated that an employment relationship happen when a work agreement between the entrepreneur or business owner and the worker/labourer exists. Then, it was further stated that the employment relationship must meet three elements, namely work (Article 1601 of the Civil Code and Article 341 of the Commercial Code), wages (Article 1603 of the Civil Code) and orders (Article 1603 of the Civil Code).

Although Article 1 number 15 of the UUK has explicitly included elements of a work agreement, in the 
view of legal experts, it is necessary to include another element in the form of a specific time element which is explained as follows:

1. Work

It is not possible for employers to recruit workers/labourers without considering the needs of the company. Normatively, work is included in one of the legal criteria of a work agreement as regulated in Article 52 Paragraph (1) of the UUK whose original rule derives from Article 1320 of the Civil Code. In this article, work is an objective requirement. Thus, a work agreement is null and void if these objective conditions are not met.

2. Wages

Workers/employees/labourers will definitely receive wages to meet their needs. Article 90 Paragraph 1 of the UUK explains that entrepreneurs are strictly prohibited from paying wages lower than the minimum wage as stipulated in Article 89 of the UUCK.

3. Order

The strategic position of entrepreneurs is that they have a stronger bargaining position than the workers/labourers. Therefore, the entrepreneur has the prerogative. Employers can give orders to workers/ labourers in accordance with the criteria and needs of the company. This makes workers/labourers integrate themselves with the company through the orders of the entrepreneur. According to most legal experts, this fact is called dienstverhoeding, in other words, workers/labourers must be willing to work under the orders of the entrepreneur.

4. Specific Time

The duration of entrepreneur and the worker/labourer working relationship can be minimized or regulated according to the agreement of the parties. Specified time is indeed not included in the interpretation of the employment relationship, as stated in Article 1 number 15 of the UUK. Given the fact that this factor is related to the implementation of a working relationship, since it is impossible for a working relationship to be carried out without mentioning the specific time needed. In addition, the regulation of the employment relationship duration also concerns the certainty and status of the parties in an employment relationship (Arifuddin Muda Harahap, 2020:71).

This specific time factor has three interpretations. First, specified time of working relationship will not force workers/labourers to work without specific duration. Therefore, work relations shall arrange definite duration to minimize the occurrence of violations of rights and obligations between entrepreneurs and workers/labourers. Employees have the right to rest and leave. Thus, the arrangement of work duration s made based on the agreement of both parties. Second, workers/labourers shall not violate the agreement since it may be harmful for all parties involved. Third, there shall be no work relations applicable for life.

In this era of digital, the effort of protecting workers shall readapt to the existing Manpower Law in Indonesia. By the development of more flexible work relations, the UUK needs to rearrange type of the relationship and its social protection. The wages mechanism does not adapt monthly payment anymore. The Law requires an hourly and daily wage ecosystem regulator that is in accordance with the growth of the existing work bond. The workforce Indonesian labourer is low, thus government shall provide a strong legal basis to guarantee workers rights for improving their competence. The improvement of employment social insurance shall not burden entrepreneurs, but it must be aimed at expanding the benefits of existing social security to be more tangible (Yeni Nuraeni, 2020: 1).

The decision on judicial review of article 164 paragraph 3 of the UUK by the Constitutional Court has made a clear understanding of efficiency in which employers may only make layoffs if the company has a high potential for being permanently closed down. The interpretation of efficiency contained in the labour law includes reducing wages and facilities for top-level workers, minimizing the division of work time, eliminating overtime work, minimizing work duration, taking employment termination gradually by not extending contracts for workers whose contract period has expired, and distributing retirement fees for those who meet the requirements.

Protection of workers/labourers can be implemented through the distribution of guidance, compensation, or clearly increasing the recognition of human rights, physical and socio-economic protection through the norms that apply in the industry, thus, it is theoretically known as 3 types of work protections as follows (Zaeni Asyhadie, 2007: 51-54):

1. Social protection is aimed at giving workers/labourers opportunity to improve their life as human being especially as members of the community and a family. This protection is also known as occupational health.

2. Technical protection is related to certain efforts to protect workers/ labourers from the dangers of disasters that can be caused by work equipments or materials. This protection is often referred to as work safety.

3. Economic protection is closely related to all efforts to provide workers/ labourers with an adequate 
income aiming to meet the daily needs of workers/ labourers and their families, including in the case they are no longer able to work beyond their will. This type of protection is also referred to as social security.

The UUK has regulated termination of employment provisions. Article 151 Paragraph (2) stated that if termination cannot be avoided, the entrepreneur shall explain to the workers/labourers or the trade union about the motives. It may seem to be multi-interpreted that the Law is allowing unilateral termination. However, the Paragraphs (3) and (4) explained that workers/labourers have been notified and refused to terminate their employment relationship, the settlement of termination of employment must be tried through bipartite, if Bipartite negotiations as defined in paragraph (3) do not obtain a consensus, then the settlement of work termination issue must take litigation through the Industrial Relations Court.

In short, the provisions of UUCK concerning termination of employment are described as follows:

a. Refusing employment termination is hard since the workers/labourers do not understand their rights at work. For it often causes them to be unable to defend their rights.

b. The UUK prevents unilateral termination of employment from taking place into two things, namely the obligation to conduct consensus deliberation through bipartite meetings and if the agreement does not find any solution, both parties can take litigation through the Industrial Relations Court as previously explained in the UUK section.

The social justice theory is the branch of Rawls theory of justice. The main idea contained in theory of justice is also applicable to social justice theory. As well as the philosophical thought that has been rooted and built the concept of ideal social justice (I Nyoman Putu Budiarta, 2012:20). The scope of social justice theory derives from neo-liberalism in England which demands equity of opportunity and minimum standard of living, while neo-liberalism of France socialist requires affirmative policies from the state through the issuance of laws and regulations on social sector. Thus, disparity of difference and inequality among human being can be connected (The Liang Gie, 1979:40).

Ernest Baker, from idealist, in The Liang Gie mentioned that social justice shall be the main foundation for the community's life which prioritizes togetherness and kinship to build the potentials of all levels of society (The Liang Gie, 1979: 5). The social justice as the value of Pancasila is applied by all levels of society through their representatives in the House of Representatives to create pro-people legislation products. In the future, Indonesia will be able to become a truly modern country by carrying out the best ideas from the content of the precepts of social justice, as a component of our nation's children, we are obliged to realize the noble ideals of the nation and state.

According to Mohamad Hatta (The Liang Gie, 1979: 5), social justice for all Indonesian people means that: a decisive step to realize a just and prosperous Indonesia. Indonesian leaders who drafted the 1945 Constitution have the belief that the ideal of social justice in the economic field is able to achieve equitable prosperity. This thought has arisen since he was elected as the head of Indonesian Association in 1926. He had delivered a speech entitled Economische Wereldbouw en Machtstegenstellingen (World Economic Structure and Conflicts of Power). His speech aimed at analysing the world economic structure to become the reference for Indonesia which favours the small people. A great era has been born by centuries, but the great age meets small humans. This quote from the great German poet, Schiller, underscores Hatta's conscience in feeling the pain and disappointment of Soekarno who deviated from his ideal of democracy. Hatta was a phenomenal figure in his time (Salman Alfarizi, 2020: 119).

The idealism of Hatta is an attempt to revolt the invaders who have been exploiting the Indonesian people. Indonesia must be independent to be able to defend from the massive imperialism barrier at that time. Finally, after a long struggle, Indonesia got the independence through the Proclamation of August 17, 1945 (Salman Alfarizi, 2020: 119).

Social justice is not only the basis of the state, but also a goal that shall be implemented. Meanwhile, Soekarno's ideals of social justice were formulated as Indonesian socialism: "A zonder society of capitalism" (Bur Rasuanto, 2005: 216), and an independent Indonesia will have no poverty (The Liang Gie, 1979: 40). From the Soekarno-Hatta description above, the notion of social justice is articulated as the welfare of the people.

Social justice needs to be connected with the Pancasila perspective, Notonagoro said that the fifth principle of social justice for all Indonesian people is divine justice, contains human values, and democracy which prioritizes deliberation and consensus. This concept must be applied by the state, because the essence of the state purpose is to create a just and prosperous society (I Nyoman Putu Budiarta, 2012: 20.). In interpreting the principles contained in the 1945 Constitution of the Republic of Indonesia, it is necessary to understand that social justice means all Citizens have the same rights and status before the law.

\section{Conclusion}

There are several aspects of legal protection for workers who have been terminated in the labour regime in Indonesia, namely. First, the aspect of Economy. Entrepreneurs are obliged to provide severance and reward 
pays for terminated workers based on the provision of existing laws ad regulations. Thus, they have the opportunity to make a living for their families; Second, the social aspect. This ideal is realized by the implementation of several insurance programs, namely Health Care Insurance (JPK), Pension Plan (JHT) and Death Insurance (JK); Third, the aspect of granting an access to work which consists of Health Care Insurance (JPK), Pension Plan (JHT) and Death Insurance (JK).

The legal principles to provide legal protection for workers being terminated are, first, the principle of legal protection certainty for workers and their families. Employers must provide definite guarantees in the form of a written legal commitment to provide legal protection in the form of compensation to workers and their families due to termination of employment caused by industrial digitization; Second, the principle of justice to receive compensation. Compensation given to workers functionally shall meet a decent standard of needs where workers and their families live; third, the principle of mutual will of the parties in the working relationship. The final decision on the termination of employment by the entrepreneur must reflect the collective will as a compromise to prevent industrial relations disputes; Fourth, the principle of authoritative intervention. The decision to terminate employment shall first obtain government approval through authoritative recommendations because termination due to industrial digitalization is usually massive and sensitive to the welfare of workers.

\section{Recommendations}

In regards to the above conclusion, some recommendations are compiled to follow up the existing ideas. First, un urgent effort is needed by the legislator to formulate technical rules and regulations, a regulation that demand entrepreneurs to make strategic plans for providing proportional job vacancies in the digital era to maintain the constitutional rights as worker.

Second, acceleration is required on the formulation of technical regulations as an effort of optimizing labour inspection system by the government in order that the reinforcement of legal protection for labours can be realized properly. Especially legal certainty of workers rights after termination aiming to provide comprehensive legal protection for workers.

\section{References}

Rifkin, J. (1996). End of work. Los Angeles: Pacifica Radio Archive.

Harianto, Aries. (2016). Hukum ketenagakerjaan: Makna kesusilaan dalam perjanjian kerja. Yogyakarta: LaksBang PRESSindo.

Harianto, Aries. (2021). Problema Hukum Ketenagakerjaan. Second Edition. Malang: Media Nusa Creative.

Harianto, A. (2013). Makna "Tidak Bertentangan dengan Kesusilaan" sebagai Syarat Sah Perjanjian Kerja (Doctoral dissertation, Universitas Brawijaya).

Sari, P., Vista, R., Harianto, A., \& Oka Ana, I. B. (2018). Kepastian Hukum Pengaturan Penggunaan Tenaga Kerja Asing di Indonesia. Lentera Hukum, 5, 389.

Utomo, Y. R., \& Harianto, A. (2018). Hak Konstitusional Pekerja/Buruh Sebagai Pengurus Serikat Pekerja/Serikat Buruh. Fairness and Justice: Jurnal Ilmiah Ilmu Hukum, 16(2).

https://finance.detik.com/moneter/d-4386840/digantikan-mesin-50000-karyawan-bank-di-ri-kena-phk , accessed on October $7^{\text {th }}, 2019$.

https://ekbis.sindonews.com/read/1357343/34/digitalisasi-ancam-ratusan-juta-pekerjaan- 1543109531,accessed on October $18^{\text {th }}, 2019$.

The Indonesian Constitution Number 13 of 2003 concerning Manpower Law Articles 154 to 172

Agusmidah, 2011, Dilematika Hukum Ketenagakerjaan, Tinjauan Politik Hukum, Jakarta:Sofmedia. p. 214-216.

Suliati Rahmat, Upaya Peningkatan Perlindungan Hukum Wanita Pekerja di Perusahaan Industri Swasta Dissertation, (Jakarta:Postragudate Program of Universitas Indonesia, 1996), p. 10.

Soerjono Soekanto dan Sri Mamudji, Penelitian Hukum Normatif Suatu Tinjauan Singkat, (Jakarta: Raja Grafindo Persada, 2007), p. 6.

Peter Mahmud Marzuki, Penelitian Hukum (Edisi Revisi), (Jakarta:Prenadamedia Group (Divisi Kencana): 2019), p. 29-36.

Peter Mahmud Marzuki, Penelitian Hukum (Edisi Revisi), (Jakarta:Prenadamedia Group (Divisi Kencana): 2019), p. 60.

Dyah Ochtorina Susanti dan A'an Efendi, Penelitian Hukum (Legal Research), (Jakarta: Sinar Grafika, 2014), p. $115-116$

G. Kartasapoetra, Hukum Perburuhan di Indonesia Beedasarkan Pancasila (Jakarta: Sinar Grafika, 1992), p. 161.

Herowati Poesoko, Diktat Metode Penulisan dan Penelitian Hukum, Jember: Faculty of Law Universitas

Jember, 2012, p. 36.

Peter Mahmud Marzuki, (2005), Penelitian Hukum, Jakarta : Prenada Media, p.29 -36.

Peter Mahmud Marzuki, (2005), Penelitian Hukum, Jakarta : Prenada Media, p134. 
Peter Mahmud Marzuki, (2005), Penelitian Hukum, Jakarta : Prenada Media, p 166.

Philipus M.Hadjon, Tatik Sri Djatmiati, (2005). Argumentasi Hukum, (2005). Yogyakarta : Gajah Mada University Press, p. 1.

Philipus M. Hadjon, Perlindungan Hukum Bagi Rakyat di Indonesia: Sebuah Studi Tentang Prinsip-Prinsipnya, Penanganannya oleh Pengadilan dalam Lingkungan Peradilan Umum dan Pembentukan Peradilan Administrasi Negara, (Surabaya:PT. Bina Ilmu, 1987), p. 25.

CST Kansil. Pengantar Ilmu Hukum dan Tata Hukum Indonesia, (Jakarta:Balai Pustaka, 1989), h. 102

Setiono, Rule of Law (Supremasi Hukum), (Surakarta:Magister Ilmu Hukum Program Pasca sarjana Universitas Sebelas Maret, 2004), p. 3

Politikana.com. accessed on August 12 $2^{\text {th }}, 2012$

Black Henry Campbell, Black's Law Dictionary, With Pronunciations, Abidged Sixth Edition, Centennial Edition (1891-1991), St. Paul Minn, West Publishing Co, 1991, p. 605.

Perjanjian Kerja Bersama PT Bank Central Asia, Tbk 2012-2014, 2012: 2

Asri Wijayanti, Hukum Ketenagakerjaan Pasca Reformasi, (Jakarta : Sinar Grafika, 2010), p.112.

UU NRI No. 13 tahun 2003 tentang Ketenagakerjaan ( Lembaran Negara Republik Indonesia Tahun 2003 Nomor 39 )

Muhammad Sadi dan Sobandi, Hukum Ketenagakerjaan di Indonesia, (Jakarta: Kencana, 2020) p. 21.

Naskah Komperhensif Perubahan Undang-Undang Dasar Negara Republik Indonesia Tahun 1945, Latar Belakang, Proses dan Hasil Pembahasan, 1999-2002. (Internal Edition)

Christine Kaufmann, Globalisation And Labour Rights: The Conflict Between Core Labour Rights And International Economic Law (Bloomsbury Publishing, 2007), p. 129.

Qiu Yang, ILO Fundamental Conventions and Chinese Labor Law: From a Comparative Perspective, Chinese L. \& Pol'y Rev., Vol. 2, No. 2006: p. 19.

Jordi Agusti-Panareda, Franz Christian Ebert, dan Desirée LeClercq, ILO Labor Standards and Trade Agreements: A case for consistency, Comp. Lab. L. \& Pol'y J., Vol. 36, No. 2014: p. 350.

Lammy Betten, International Labor Law (HeinOnline, 1993), p. 22.

Otto Kahn-Freund Dkk., Kahn-Freund's Labour And The Law (Stevens London, 1983), p. 121.

Arturo S. Bronstein, Protection Against Unjustified Dismissal In Latin America, Int'1 Lab. Rev., Vol. 129, No. 1990: p. 599.

Simon Deakin Dan Frank Wilkinson, Rights Vs Efficiency-The Economic Case For Transnational Labour Standards, Indus. Lj, Vol. 23, No. 2, 1994: p. 290.

Sean Cooney, Testing Times For The ILO: Institutional Reform For The New International Political Economy, Comp. Lab. L. \& Pol'y J., Vol. 20, No. 1998: p. 365.

Stephen L. Schlossberg, United States' Participation In The ILO: Redefining The Role, Comp. Lab. LJ, Vol. 11, No. 1989: p. 60.

David Weissbrodt Dan Matthew Mason, Compliance Of The United States With International Labor Law, Minn. L. Rev., Vol. 98, No. 2013: p. 1843.

Lee Swepston, The Future of ILO standards, Monthly Labor Review, Vol. 117, No. 9, 1994: p. 350.

Sendjun H. Manulang, Pokok-Pokok Hukum Ketenagakerjaan Indonesia (Jakarta: Rineka Cipta, 1990), p. 20.

Imam Soepomo, Hukum Perburuhan Bagian Pertama Hubungan Kerja (Jakarta: PPAKRI Bhayangkara, 1968), p. 3 .

Melania Kiswandari, Kesehatan dan Keselamatan Kerja, (Jakarta: Rajawali Pers, 2014), p. 78.

S. H. Hidayat Muharam, Panduan Memahami Hukum Ketenagakerjaan Serta Pelaksanaannya Di Indonesia (Jakarta: Citra Aditya Bakti, 2006), p.8.

FORKOMSI FEB UGM, 2019: 161

Astrid Savitri, Revolusi Industri 4.0: Mengubah Tantangan menjadi Peluang di Era Disrupsi 4.0 (Bantul: Genesis,2019) p.2-4.

efisiensi Sebagai Alas Pemutusan Hubungan Kerja, Business Law, accessed on July 28 ${ }^{\text {th }}$, 2021, https://businesslaw.binus.ac.id/2016/09/28/efisiensi-sebagai-alas-pemutusan-hubungan-kerja

Andika Pramana Putra, Kajian Hukum Terhadap Putusan Mahkamah Agung Atas Perkara No. 825k/Pdt. SusPhi/2015 Tentang Pemutusan Hubungan Kerja Karena Alasan Efisiensi, Jurnal Hukum Adigama, Vol. 1, No. 1, (t.t.): p. 770.

Abi Pasha Nugraha, Efisiensi usaha sebagai alasan pemutusan hubungan kerja Perspektif Hukum Islam: Putusan Mahkamah Agung Nomor 69 K/Pdt. Sus-PHI/2017 (Dissertation, Malang, Universitas Islam Negeri Maulana Malik Ibrahim, 2020), p. 102.

Abdul Khakim, Pengantar Hukum Ketenagakerjaan Indonesia Berdasarkan Undang-Undang No. 13 Tahun 2003 (Bandung: Citra Aditya Bakti, 2003), p. 12,

I. Made Udiana, Industrialisasi dan Tanggungjawab Pengusaha Terhadap Tenaga Kerja Terlibat Hukum (Denpasar: Udayana University Press, Denpasar, 2018), p. 26. 
Ashabul Kahfi, Perlindungan Hukum Terhadap Tenaga Kerja, Jurisprudentie: Jurusan Ilmu Hukum Fakultas Syariah dan Hukum, Vol. 3, No. 2, 2016: p. 62.

Cristoforus Valentino Alexander Putra, Urgensi Klausula Definisi Dalam Perjanjian Kerja, Jurnal Ilmiah Fakultas Hukum Universitas Udayana, Vol. 63, No. 2017: p. 68.

Siti Kunarti, Perjanjian Pemborongan Pekerjaan (Outsourcing) Dalam Hukum Ketenagakerjaan, Jurnal Dinamika Hukum, Vol. 9, No. 1, 2009: p. 70.

Agung Prasetyo Wibowo, Perlindungan Hukum Terhadap Pekerja Dalam Pemutusan Hubungan Kerja Dengan Alasan Efisiensi Sebagai Akibat Pandemi Covid 19 (Studi Kasus Putusan Pengadilan Hubungan Industrial Pada Pengadilan Negeri Palangkaraya Perkara No. 10/Pdt. Sus-PHI/2020/PN Plk (Disertasi, Universitas Tarumanagara, 2021), p. 76.

Kadek Agus Sudiarawan dan Nyoman Satyayudha Dananjaya, Konsep Penyelesaian Perselisihan Hubungan Industrial Berbasis Pemberdayaan Sebagai Upaya Peningkatan Perlindungan Hukum Terhadap Buruh Dalam Mencari Keadilan, ADHAPER: Jurnal Hukum Acara Perdata, Vol. 3, No. 1, 2018: p. 20.

Kadek Agus Sudiarawan dan Nyoman Satyayudha Dananjaya, Konsep Penyelesaian Perselisihan Hubungan Industrial Berbasis Pemberdayaan Sebagai Upaya Peningkatan Perlindungan Hukum Terhadap Buruh Dalam Mencari Keadilan, ADHAPER: Jurnal Hukum Acara Perdata, Vol. 3, No. 1, 2018: p. 797.

Siti Ummu Adillah Dan Sri Anik, Kebijakan Jaminan Sosial Tenaga Kerja Sektor Informal Berbasis Keadilan Sosial Untuk Meningkatkan Kesejahteraan, Yustisia Jurnal Hukum, Vol. 4, No. 3, 2015: p. 560.

Dodi Satriawan, Agus Joko Pitoyo, dan Sri Rum Giyarsih, Cakupan Kesehatan Universal (UHC) Pekerja Sektor Informal di Indonesia, Tata Loka, Vol. 22, No. 4, 2020: p. 558.

Ida Ayu Sadnyini dan Milton Gabe L. Tobing, Jaminan Sosial Ketenagakerjaan Terhadap Pekerja Harian Hotel Bintang Lima Di Kabupaten Badung, Soumatera Law Review, Vol. 3, No. 1, 2020: p. 109.

Hartini Retnaningsih, Strategi Sistem Jaminan Sosial Nasional Bidang Ketenagakerjaan Dalam Upaya Pelindungan Pekerja Di Kota Surabaya Dan Kota Pekanbaru, Aspirasi: Jurnal Masalah-masalah Sosial, Vol. 7, No. 2, 2019: p. 167.

Arifuddin Muda Harahap, Pengantar Hukum Ketenagakerjaan (Malang: Literasi Nusantara, 2020).p.71.

Yeni Nuraeni, Analisis Terhadap Undang-Undang Ketenagakerjaan Indonesia Dalam Menghadapi Tantangan Revolusi Industri 4.0, Jurnal Ketenagakerjaan, Vol. 15, No. 1, 2020.

Zaeni Asyhadie, Hukum Kerja, Hukum Ketenaga Kerjaan Bidang Hubungan Kerja, (Jakarta: RajaGrafindo Persada Jakarta, 2007), p. 51-54.

Wirjono Prodjodikoro, Asas-Asas Hukum Perdata Internasional (Bandung:Sumur Bandung, 1979). p. 9.

I Nyoman Putu Budhiarta, Perlindungan Hukum Pekerja Outsourcing Ditinjau Dari Prinsip Keadilan, Kepastian Hukum, Dan Hak Asasi Manusia. (Dissertation) Faculty of Law, Universitas Brawijaya, 2012, p.20.

The Liang Gie, Teori-Teori Keadilan, (Yogyakarta:Penerbit Super, 1979,) p. 5

The Liang Gie, Teori-Teori Keadilan, (Yogyakarta:Penerbit Super, 1979,) p. 40

Salman Alfarizi, Mohammad Hatta: Biografi Singkat (1902-1980), (Yogyakarta:Garasi, 2020), p.119. 